Cite this: RSC Adv., 2019, 9, 40228

Received 22nd August 2019

DOI: $10.1039 / c 9 r a 06612 \mathrm{~h}$

rsc.li/rsc-advances
Check for updates

Accepted 19th November 2019

\section{Potassium 2-methoxy-4-vinylphenolate: a novel hit exhibiting quorum-sensing inhibition in Pseudomonas aeruginosa via LasIR/RhlIR circuitry $\dagger$}

\author{
Mayank D. Shah, ${ }^{a}$ Prashant S. Kharkar, (D) ${ }^{\mathrm{b}}$ Niteshkumar U. Sahu, ${ }^{\mathrm{b}}$ Zoya Peerzada ${ }^{\mathrm{a}}$ \\ and Krutika B. Desai (D) *c
}

\begin{abstract}
The emergence of multidrug-resistant (MDR) bacterial strains in the last decade is astonishingly alarming. Many of the widely used antibiotics have failed to exhibit clinical efficacy against such strains. Eventually we will exhaust all the resources in our antibiotic armamentarium. As a need of the hour, novel strategies are desperately required not only to curb, but also to reverse, the development of resistance in these pathogens, thereby maintaining their sensitivity towards current antibiotics. Intervention of bacterial virulence, rather than killing them, by inhibiting specific pathways/targets has emerged as a novel approach to tackle the drug resistance problem. The bacterial virulence is regulated via quorum-sensing, a cell-cell communication process precisely controlled by autoinducer molecules such as acyl homoserine lactone (AHL). The present study aimed at identifying promising quorum-sensing inhibitors in Pseudomonas aeruginosa, an opportunistic human pathogen especially associated with nosocomial infections, yielding four potential hits. Out of these, potassium 2-methoxy-4-vinylphenolate was the most potent quorum-sensing inhibitor targeting $P$. aeruginosa LasIR/RhlIR circuitry. It also inhibited biofilm formation, various virulence factors like LasA protease, LasB elastase and pyocyanin, and motility of bacteria like swarming and twitching.
\end{abstract}

\section{Introduction}

The past decade has witnessed a surge in antibiotic resistance. Several, otherwise antibiotic-sensitive microbes, have become resistant, leading to utter therapeutic failure. The World Health Organization (WHO) went to the extent of calling the $21^{\text {st }}$ century as the 'Post-antibiotic era'. ${ }^{1}$ The WHO fact sheet on antimicrobial resistance (released on February 15, 2018) is concerning. ${ }^{2}$ The overall statistics indicate the gravity of the situation. Moreover, the emergence of multidrug- and pan-drug-resistant pathogens, particularly the Gram-negative ones, has made the matter worse. ${ }^{3}$ Among these pathogens, mostly responsible for the nosocomial infections, Klebsiella pneumoniae, Acinetobacter baumannii, and Pseudomonas aeruginosa are the front-runners. In particular, Pseudomonas aeruginosa is most dangerous. It is an aerobic, Gram-negative, opportunistic human pathogen majorly responsible for healthcare-associated infections (the sixth most

${ }^{a}$ Sunandan Divatia School of Science, SVKM's NMIMS (Deemed to be University), Mumbai, 400056, India

${ }^{b}$ Institute of Chemical Technology, Category I Deemed to be University (MHRD/UGC), Mumbai-400019, India

'Mithibai College of Arts \& Science \& Amrutben Jivanlal College of Commerce \& Economics, Mumbai, 400056, India. E-mail: krutika.desai@mithibai.ac.in

$\dagger$ Electronic supplementary information (ESI) available. See DOI: $10.1039 / \mathrm{c} 9 \mathrm{ra} 06612 \mathrm{~h}$ common nosocomial pathogen) in general and ventilator-associated pneumonia (VAP) (the second most common pathogen), in particular. ${ }^{4,5}$ The emergence of multidrug-resistant (MDR) strains of Pseudomonas aeruginosa have created havoc in the not-sodistant past. ${ }^{6,7}$ Several conventional and emerging strategies have been and are being utilized to combat the disastrous situation. ${ }^{8-11}$ One such strategy is to inhibit a phenomenon named quorum sensing in these deadly pathogens. ${ }^{12}$

Quorum sensing is a bacterial cell-to-cell communication mechanism mediated by a set of chemicals known as autoinducers. ${ }^{13}$ At the core of quorum sensing process is the production, release, accumulation and population-wide detection of the autoinducers. The Gram-negative bacteria use smallmolecules while Gram-positive bacteria use oligopeptides as autoinducers. These molecules accumulate in the environment as the bacterial population density increases, and this information is monitored by the bacteria to track variations in their cell numbers and ultimately to control the gene expression. Such coordinated activities brought about via quorum sensing include bioluminescence, secondary metabolites such as antibiotics production, biofilm formation, and virulence factor secretion, to name a few..$^{14,15}$

In Pseudomonas aeruginosa, there are two circuits as integral parts of quorum sensing mechanism which are LasI/R and RhlI/ R (Fig. 1), resembling LuxI/R system in Vibrio fischeri. ${ }^{16}$ The LasI/ $\mathrm{R}$ and $\mathrm{RhlI} / \mathrm{R}$ produce small-molecule autoinducers, $\mathrm{N}$-3-oxo- 


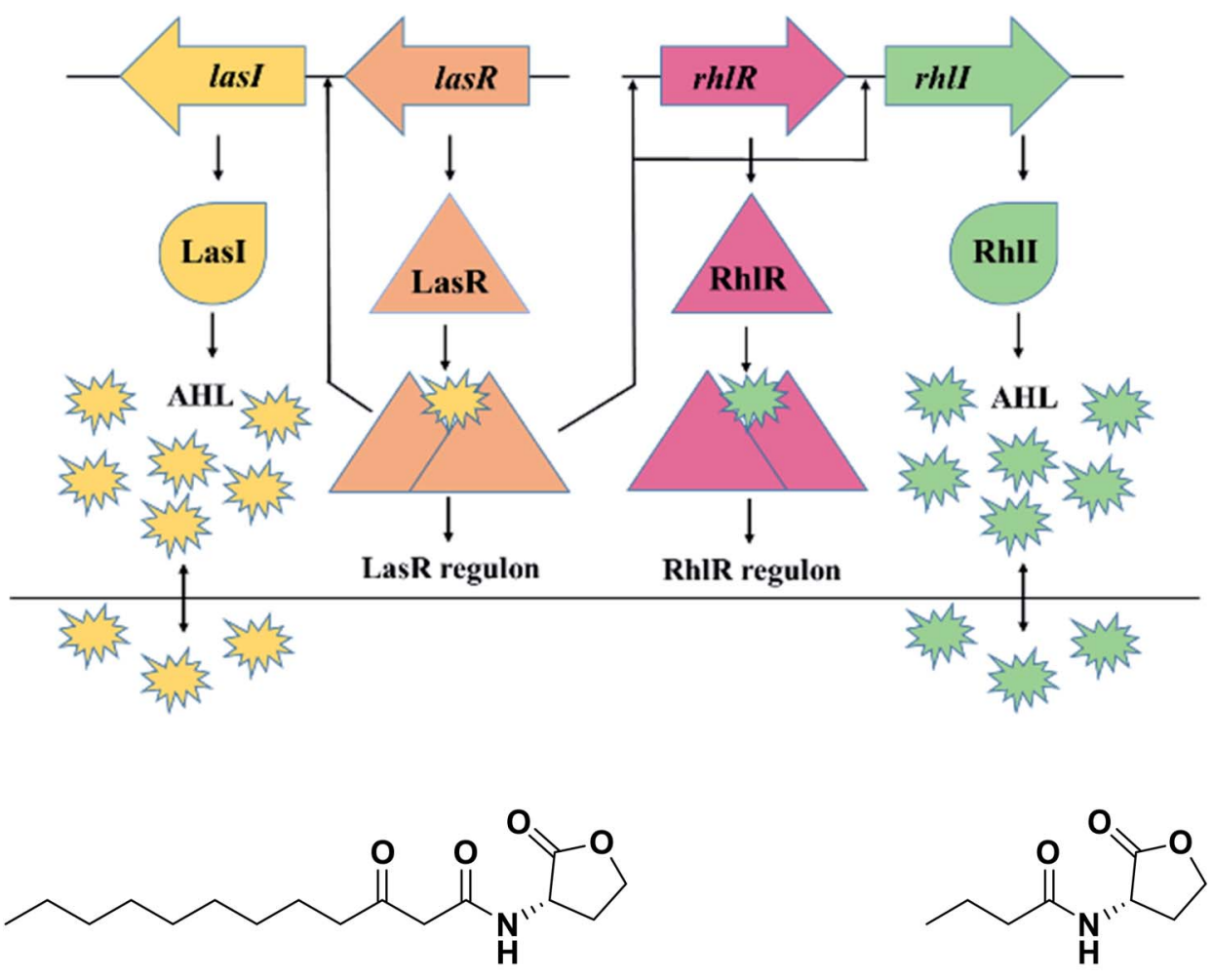

Fig. 1 Quorum sensing in Pseudomonas aeruginosa; AHL: acyl homoserine lactone; 1: N-3-oxo-dodecanoyl homoserine lactone (3OC12-HSL); 2: N-butanoyl-L-homoserine lactone (C4-HSL).

dodecanoyl homoserine lactone (3OC12-HSL) and C4-homoserine lactone (C4-HSL), respectively. ${ }^{17,18}$ These molecules bind to their cognate receptors forming the autoinducer-receptor complex, which ultimately regulates various downstream molecules/processes including virulence factors like LasA protease, LasB elastase, pyocyanin (PCN), swarming and twitching activity and biofilm formation. Given the importance of quorum sensing in the bacterial virulence and biofilm formation, its inhibition has emerged as an important strategy to tackle the menace of MDR and pan-drug-resistant (PDR) bacterial pathogens. ${ }^{19,20}$ The concept is very simple. By interfering with their virulence factors and not killing them via inhibition of quorum sensing, we are in a way slowing down the emergence of MDR and PDR strain. Thanks to the weaker selective pressure exerted on bacteria by these mechanisms!

Due to the promise offered by quorum sensing inhibition, it is not surprising that a variety of small-molecules (synthetic as well as natural products) with significant antiquorum sensing and antibiofilm activities in Gram-negative and Gram-positive bacteria have been reported. ${ }^{21-24}$ Literature is full of reports particularly on quorum sensing inhibition in Pseudomonas aeruginosa..$^{25-36}$

Carvacrol (essential oil) was reported to inhibit biofilm formation in $S$. aureus and $P$. aeruginosa and pyocyanin production in $P$. aeruginosa significantly. ${ }^{37}$ Baicalein (flavonoid from the roots of Scutellaria baicalensis) was demonstrated to inhibit several virulence factors and biofilm formation. ${ }^{38}$ Another interesting study revealed that [6]-gingerol, a pungent active from fresh ginger which is structurally analogous to 3OC12-HSL, reduced biofilm formation, virulence factors such as pyocyanin, exoprotease and rhamnolipid and mice mortality. ${ }^{39}$ The in silico studies confirmed that [6]-gingerol bound specifically to LasR receptor. The QS genes involved in production of virulence factors were specially repressed as seen from the transcriptome analysis.

Working on the similar lines, Gala et al. (author's lab) identified active components from Tinospora cordifolia (family: Menispermaceae, common name: Guduchi) following isolation and identification using column chromatography, gas chromatography-mass spectrometry (GC-MS) and in silico molecular studies as potential anti-quorum sensing inhibitors. ${ }^{40}$ Four molecules, namely 2,3,4-triacetoxybutyl acetate (3), 2-(5-ethenyl-5methyloxolan-2-yl)propan-2-ol (4), methyl hexadecanoate (5) and 2-methoxy-4-vinylphenol (6) (Fig. 2) were postulated to inhibit QS via either LasI or LasR. ${ }^{41}$ We were the first to report these molecules as potential QS inhibitors. Interestingly, the partial structural similarity of $\mathbf{5}$ and $\mathbf{6}$ with previously reported [6]-gingerol was intriguing, which further strengthened our belief that these 
<smiles>CC(=O)OCC(OC(C)=O)C(COC(C)=O)OC(C)=O</smiles>

3

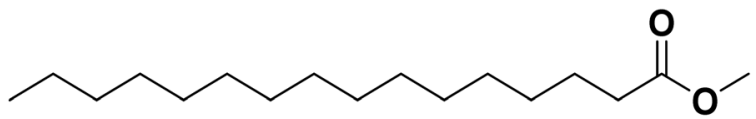

5

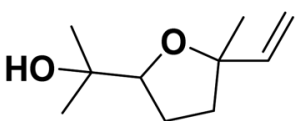

4

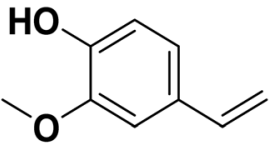

6

Fig. 2 Previously reported lead structures from Tinospora cordifolia: 2,3,4-triacetoxy-butyl acetate (3), 2-(5-ethenyl-5-methyloxolan-2-yl) propan-2-ol (4), methyl hexadecanoate (5) and 2-methoxy-4-vinylphenol (6).

leads would provide us newer chemotypes for QS inhibitors. In the present study, we report further profiling of these leads (3-6, Fig. 2) by quorum quenching studies against $P$. aeruginosa. Although the major issue with compound $\mathbf{6}$ was its significantly lesser aqueous solubility. We were determined to improve its aqueous solubility by suitable structural and/or chemical modification. Herein, we describe the complete profiling of modified compound 6 as a potential QS inhibitor in a battery of assays validating the original observations and the hypothesis.

\section{Material and methods}

\subsection{General}

All the chemicals such as 2-(5-ethenyl-5-methyloxolan-2-yl) propan-2-ol (4, Fig. 2), erythritol, 2-methoxy-4-vinyl phenol and elastin congo red (ECR), propidium iodide, solvents and reagents were purchased from the approved vendors such as Acros Organics (Geel, Belgium), Alfa Aesar (Karlsruhe, Germany), Spectrochem (Mumbai, India), Sigma-Aldrich (Steinheim, Germany, St. Louis, MO, USA) or Merck (Darmstadt, Germany) and used without further purification unless otherwise indicated. SYTO-9 dye was purchased from Thermo Fisher, Waltham, MA. Reactions were carried out under dry $\mathrm{N}_{2}$ atmosphere and thin-layer chromatography (TLC), wherever required, was performed using an aluminum plate coated with silica gel $60 \mathrm{~F}_{254}$ (Merck Millipore, Billerica, MA, USA). 2Methoxy-4-vinyl phenol was purchased from Alfa Aesar by Thermo Fisher Scientific (Tewksbury, MA). Melting points were recorded using conventional Thiele tube and are uncorrected. The NMR spectra were recorded in either in $\mathrm{CDCl}_{3}$ or DMSO- $d_{6}$ with tetramethylsilane (TMS) as internal standard. FT-IR spectra were recorded on PerkinElmer RX1 instrument (Waltham, MA). ${ }^{1}$ H-NMR spectra were obtained on Bruker Advance 400 (400 MHz) spectrometer. Mass spectra (MS) were recorded either on a Shimadzu 8040 LC-MS/MS system (Japan), or Agilent
Infinity 1290 series (Agilent Technologies, USA) instrument coupled with quadrupole time of flight (iFunnel Q-TOF LC-MS 6550) and equipped with electrospray ionization (ESI) mode.

Pseudomonas aeruginosa PAO1 strain was used as a standard strain for evaluation of all antiquorum, antibiofilm and antivirulence activity studies. Staphylococcus aureus 737 was used for LasA protease study. Chromobacterium violaceum ATCC 12472 and Escherichia coli MG4/pKDT17 were used as a reporter strain in variety of assays. Luria Bertani (LB) broth and agar powder were purchased from Himedia Laboratories, Mumbai, India. $o$-Nitrophenyl-4-D-galactopyranoside (ONPG) was purchased from Sisco Research Laboratories (SRL), Mumbai, India. Rest of the chemicals were purchased from Qualigens Fine Chemicals, Mumbai, India. E. coli MG4/pKDT17 was grown in LB medium containing $100 \mu \mathrm{g}$ ampicillin. All other bacterial strains were incubated overnight at $37^{\circ} \mathrm{C}$, wherever required.

\subsection{Synthesis of test compounds}

2.2.1. 2,3,4-Triacetyloxybutyl acetate (3). A mixture of erythritol ( $1 \mathrm{~g}, 8.19 \mathrm{mmol})$, anhydrous NaOAc $(6.7 \mathrm{~g}, 81.9 \mathrm{mmol}$, 10 equiv.) and acetic anhydride $(7.75 \mathrm{~mL}, 81.9 \mathrm{mmol}, 10$ equiv.) and was heated on water-bath at $90{ }^{\circ} \mathrm{C}$ until a clear solution was obtained (approx. $2 \mathrm{~h}$ ). The reaction was monitored by LC-MS. Once completed, the reaction mixture was poured on crushed ice and stirred for further $15 \mathrm{~min}$. The precipitated solid was filtered under vacuum, washed with cold water and dried in oven. The crude product was recrystallized from 95\% EtOH to get pure compound. Yield: $0.72 \mathrm{~g}$; melting point: $86-88^{\circ} \mathrm{C}$; MS (ESI): $308.10\left[\mathrm{M}+\mathrm{H}_{2} \mathrm{O}\right]^{+}$; FT-IR $\left(\mathrm{KBr}, \mathrm{cm}^{-1}\right): 2964(\mathrm{C}-\mathrm{H}$ stretching), 1743 (C=O stretching), 1242, 1220 (C-O-C stretching).

2.2.2. Methyl palmitate (5). Palmitic acid (5 g) was dissolved in MeOH HPLC and few drops of conc. $\mathrm{H}_{2} \mathrm{SO}_{4}$ added. The reaction mixture was refluxed on water-bath for $5 \mathrm{~h}$. The 
reaction was monitored by GC. After completion, the solvent was evaporated and the syrupy liquid was taken up in dry DCM. The organic layer was washed with sat. $\mathrm{NaHCO}_{3}(2 \times 20 \mathrm{~mL})$, followed by water $(2 \times 20 \mathrm{~mL})$. The organic layer was dried (anhyd. $\mathrm{Na}_{2} \mathrm{SO}_{4}$ ) and the solvent removed in vacuo to obtain pure product. Yield: $4.67 \mathrm{~g}$; melting point: $32-34{ }^{\circ} \mathrm{C}$; MS (ESI): 271.27; FT-IR (KBr, $\mathrm{cm}^{-1}$ ): 2924 (C-H stretching), $1744(\mathrm{C}=\mathrm{O}$ stretching), 1171, 1198 (C-O-C stretching).

2.2.3. Potassium 2-methoxy-4-vinylphenolate (7) (Scheme 1). A mixture of 2-methoxy-4-vinyl phenol (6) (1 g, $3.33 \mathrm{mmol})$, anhydrous $\mathrm{K}_{2} \mathrm{CO}_{3}(0.24 \mathrm{~g}, 1.67 \mathrm{mmol})$ and anhydrous toluene $(20 \mathrm{~mL})$ was refluxed for $12 \mathrm{~h}$ with continuous stirring attached using Dean-Stark apparatus. The reaction was monitored by TLC. After complete consumption of the starting phenol, the reaction mixture was cooled and the solid filtered, washed with anhydrous toluene and dried at $60{ }^{\circ} \mathrm{C}$ for $24 \mathrm{~h}$, when slightly yellow-colored amorphous and free-flowing powder was obtained. Yield: $0.8 \mathrm{~g}$; HRMS (ESI): $187.0406[\mathrm{M}-\mathrm{H}]^{-} ;{ }^{1} \mathrm{H}-\mathrm{NMR}$ $\left(\mathrm{DMSO}-d_{6}\right) \delta$ ppm $6.9(\mathrm{~m}, 2 \mathrm{H}), 6.6(\mathrm{~m}, 1 \mathrm{H}), 5.61(\mathrm{~d}, 1 \mathrm{H}), 5.55(\mathrm{~s}$, 1H), $5.2(\mathrm{~d}, 1 \mathrm{H}), 3.9(\mathrm{~s}, 3 \mathrm{H})$; FT-IR $\left(\mathrm{KBr}, \mathrm{cm}^{-1}\right): 2929(\mathrm{C}-\mathrm{H}$ stretching), 1630 ( $\mathrm{C}=\mathrm{C}$ stretching), 1124 (C-O-C stretch).

\subsection{Anti-quorum sensing activity}

The test compounds, dissolved in 50\% DMSO at specified concentration, i.e., $4 \mathrm{mg} \mathrm{mL}{ }^{-1}$, were screened for short acyl-HSL and long acyl-HSL inhibition according to the protocols given below. The corresponding concentrations of the test compounds were 13.7 mM (3), $14.7 \mathrm{mM}$ (4), $23.4 \mathrm{mM}$ (5) and $21.4 \mathrm{mM}$ (7).

2.3.1. Inhibition of short-chain AHL. Agar well-diffusion assay was performed to estimate the inhibition of short-chain AHL by the test compounds. The overnight grown culture of Chromobacterium violaceum ATCC12472 was mixed in $15 \mathrm{~mL} \mathrm{LB}$ agar $(1.5 \%)$. Test compounds were added in the agar well. DMSO (50\%) was used as negative control. Azithromycin dihydrate (AZ) $\left(4 \mu \mathrm{g} \mathrm{mL}^{-1}\right.$ in PBS : EtOH $1: 1$ as solvent) was used as positive control and PBS : EtOH $(1: 1)$ as its negative control. Production of pigment inhibition was checked after $24 \mathrm{~h}$ incubation. ${ }^{40}$ To support this assay quantitative analysis of violacein pigment inhibition was done. Growth curve analysis was done to confirm that compound 7 possess anti-quorum sensing activity not anti-bacterial. Bacterial growth curve was observed by measuring cell density at $600 \mathrm{~nm}$ at various time point until it reached to stationary phase.

2.3.2. Inhibition of long-chain AHL. The ability of compounds to inhibit long acyl-HSL in $P$. aeruginosa was tested using reporter strain E. coli MG4/pKDT1719 (ref. 41) where this strain is used to detect 3-oxo- or 3-hydroxy substituted or unsubstituted C8-C14 long acyl-HSLs wherein the long acylHSL induces the expression of the $\beta$-galactosidase gene. The decrease in expression of $\beta$-galactosidase is indicative the inhibition of long-chain acyl-HSL. The bacterial culture was grown along with test compounds or only the solvent (negative control) or azithromycin dihydrate $\left(4 \mu \mathrm{g} \mathrm{mL}^{-1}\right)$ (positive control) for $24 \mathrm{~h}$. Culture supernatant was then extracted with EtOAc twice and the pooled organic layers were evaporated to dryness under $\mathrm{N}_{2}$ atmosphere. The dried extract was mixed in LB broth and $2.0 \mathrm{~mL}$ of overnight grown $E$. coli MG4 culture and incubated for $5 \mathrm{~h}$ at $37^{\circ} \mathrm{C}$ for induction of $\beta$-galactosidase. The enzyme activity was determined as described by Miller using ONPG as substrate..$^{\mathbf{4 0 2}}$

\subsection{Effect of the compound on $P$. aeruginosa biofilm formation as analyzed by crystal violet assay}

Biofilm formation was checked using 96-well flat-bottom microtiter plate, as per the modified method reported by Mathur et al. (2006). ${ }^{43}$ Overnight culture of $P$. aeruginosa was diluted with fresh LB broth supplemented with $0.5 \%$ glucose, up to $0.2 \mathrm{OD}_{600}$. Then control/test compound was added. The positive control, azithromycin dihydrate, was dissolved in PBS : EtOH (1:1), pH 6.0, and 50\% DMSO/PBS : EtOH (1:1) was used as negative control. Microtiter wells were filled with $200 \mu \mathrm{L}$ aliquots of the diluted cultures as described above, uninoculated broth and uninoculated broth containing the compound. The plates were incubated for $24 \mathrm{~h}$, at $37{ }^{\circ} \mathrm{C}$. The wells were aspirated, washed with deionized water to remove the planktonic bacteria, and dried. The biofilm, formed in microtiter plate wells, was fixed with $200 \mu \mathrm{L} \mathrm{MeOH}$ for 15 min. Then the solvent was removed and the plates were dried. Next, the biofilm was stained using $200 \mu \mathrm{L}$ of $1 \%$ crystal violet dye for 15 min. Excess stain was removed and the plate washed with tap water and dried. The bound dye was resolubilized in 95\% EtOH $(180 \mu \mathrm{L})$ for $5 \mathrm{~min}$ and the absorbance at $490 \mathrm{~nm}$ recorded using BioTek Microplate reader Epoch ${ }^{\mathrm{TM}} 2 .^{40}$

2.4.1. Confocal microscopy. Overnight culture of $P$. aeruginosa (wild type) was diluted with fresh LB broth up to 0.2 $\mathrm{OD}_{600}$. Culture with the compound was inoculated on a clean, sterile glass slide under sterile condition and incubated for 24 h. Next day, the cells were washed twice with PBS ( $\mathrm{pH} 7.0)$ to remove unattached cells. SYTO- $9\left(\lambda_{\text {ex }} / \lambda_{\text {em }} 480 / 500 \mathrm{~nm}\right)$ and propidium iodide $\left(\lambda_{\mathrm{ex}} / \lambda_{\mathrm{em}} 490 / 635 \mathrm{~nm}\right)$ dyes were used for confocal study in $2: 1$ concentration. The mixture of dyes $(5 \mu \mathrm{L})$ was added onto the slide and coverslip was fixed with transparent nail paint. Samples were observed under Spinning disc confocal laser microscope (CLSM, Zeiss LSM 800, Carl Zeiss, Jena) at $40 \mathrm{X}$.

\subsection{Anti-virulence assays}

2.5.1. Swarming activity. Test compound was mixed with LB agar with positive control (azithromycin $4 \mu \mathrm{g} \mathrm{mL} \mathrm{m}^{-1}$ ) and negative control [50\% DMSO/PBS : EtOH $(1: 1)]$. The mixtures were poured onto plates and allowed to solidify. $P$. aeruginosa $(10 \mu \mathrm{L})$ was point inoculated in the middle of the plate, which were then incubated at $37{ }^{\circ} \mathrm{C}$ for $48 \mathrm{~h}$. The degree of swarming was determined by measuring the diameter of the swarm and compared with control. ${ }^{44}$

2.5.2. LasA protease. Overnight culture of $P$. aeruginosa (wild type) was diluted with fresh $\mathrm{LB}$ broth up to $0.2 \mathrm{OD}_{600}$. Test compound $(0.1 \mathrm{~mL}$, dose dependent concentration in $50 \%$

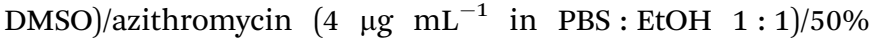
DMSO/PBS : EtOH $(1: 1)$ was added to the diluted culture (4.9 $\mathrm{mL}$ ) and further incubated at $37{ }^{\circ} \mathrm{C}$ for $24 \mathrm{~h}$. The culture was 
centrifuged at $10000 \mathrm{rpm}$ under cold $\left(4{ }^{\circ} \mathrm{C}\right)$ condition for 15 min. The culture supernatant $(0.5 \mathrm{~mL})$ was mixed with $1.5 \mathrm{~mL}$ of $15 \mathrm{~min}$ boiled suspension of Staphylococcus aureus in $0.02 \mathrm{M}$ Tris-HCl buffer ( $\mathrm{pH}$ 8.5). The $\mathrm{OD}_{600}$ was measured at 0 and $3 \mathrm{~h}$ with UV-Vis spectrophotometer (PerkinElmer Lambda 25) post incubation at $37^{\circ} \mathrm{C}^{45,46}$

2.5.3. LasB elastase. Overnight culture of $P$. aeruginosa (wild type) was diluted with fresh LB broth up to $0.2 \mathrm{OD}_{600}$. Then, $0.1 \mathrm{~mL}$ of test compound (dose dependent concentrations in $50 \% \mathrm{DMSO}$ )/azithromycin $\left(4 \mu \mathrm{g} \mathrm{mL} \mathrm{mL}^{-1}\right.$ in PBS : EtOH $\left.1: 1\right) /$ $50 \%$ DMSO/PBS : EtOH $(1: 1)$ was added to the diluted culture $(4.9 \mathrm{~mL})$ and incubated at $37{ }^{\circ} \mathrm{C}$ for $24 \mathrm{~h}$. The culture was centrifuged at $10000 \mathrm{rpm}\left(4^{\circ} \mathrm{C}\right)$. Buffer $(0.1 \mathrm{~mL}, 0.1 \mathrm{M}$ Tris, 1 $\mathrm{mM} \mathrm{CaCl}_{2}$, and $\left.\mathrm{pH} 7.5\right)$ containing ECR substrate (10 mg) was mixed with culture supernatant $(0.5 \mathrm{~mL})$, incubated at $37^{\circ} \mathrm{C}$ for $24 \mathrm{~h}$. The tubes were centrifuged at $10000 \mathrm{rpm}\left(4^{\circ} \mathrm{C}\right)$ for 10 min, and $\mathrm{OD}_{495}$ of the supernatant was measured. ${ }^{47}$

2.5.4. Pyocyanin assay. Overnight culture of $P$. aeruginosa (wild type) was diluted with fresh King's medium B up to 0.2 $\mathrm{OD}_{600}$. Test compound $(0.1 \mathrm{~mL}$, dose dependent concentration in $50 \% \mathrm{DMSO}$ )/azithromycin $\left(4 \mu \mathrm{g} \mathrm{mL}^{-1}\right.$ in PBS : EtOH $\left.1: 1\right) /$ $50 \%$ DMSO/PBS : EtOH $(1: 1)$ were added to the diluted culture $(4.9 \mathrm{~mL})$ and incubated for $48 \mathrm{~h}$ at $37{ }^{\circ} \mathrm{C}$. The culture was centrifuged at $10000 \mathrm{rpm}\left(4^{\circ} \mathrm{C}\right)$ for $15 \mathrm{~min}$. To the culture supernatant $(5 \mathrm{~mL}), \mathrm{CHCl}_{3}(3 \mathrm{~mL})$ was added, vortexed to extract blue pyocyanin in $\mathrm{CHCl}_{3}$, followed by absorbance measurement at $690 \mathrm{~nm}$. Pyocyanin concentration was calculated as $\mathrm{mg} \mathrm{mL}^{-1}$ using the formula, $\mathrm{OD}_{690} / 16^{40,48}$

2.5.5. Twitching motility assay. Compound $7(4 \mathrm{mg} \mathrm{mL}$ in $50 \% \mathrm{DMSO}$ )/AZ (4 mg $\mathrm{mL}^{-1}$ in PBS : EtOH $1: 1$ ) (positive control)/negative control (50\% DMSO/PBS : EtOH (1:1)) was mixed with LB agar. The mixtures were poured into plates and allowed to solidify. The Pseudomonas aeruginosa culture (PAO1) was stabbed to bottom in the middle of the plate. Plates were then incubated at $37{ }^{\circ} \mathrm{C}$ for $24 \mathrm{~h}$. The extent of twitching was determined by measuring the diameter of growth zone (in $\mathrm{mm}$ ), followed by comparison with the control. ${ }^{49}$

\subsection{Gene regulation}

Overnight culture of $P$. aeruginosa PAO1 $\left(\mathrm{OD}_{600}\right.$ : 0.2$)$ was inoculated with LB medium supplemented with different concentration of compound $7\left(2 \mathrm{mg} \mathrm{mL} L^{-1}\right.$ to $\left.8 \mathrm{mg} \mathrm{mL}^{-1}\right)$ and incubated at $37{ }^{\circ} \mathrm{C}$. Total RNA was extracted using TriZol and concentration and purity were determined by UV absorption (260/280 nm) using Take 3 plate in Epoc2 (BioTek). cDNA was synthesized from purified mRNA sample using PrimeScript reagent kit (TaKaRa). Real Time PCR was carried out using SYBR green master mix (Thermo scientific, USA) with StepOne Applied Biosystems (California, USA). The reaction procedure as follows: $95^{\circ} \mathrm{C}$ for $30 \mathrm{~s}, 40$ cycles of $95^{\circ} \mathrm{C}$ for $5 \mathrm{~s}$, and $60^{\circ} \mathrm{C}$ for $5 \mathrm{~s}$, and a final melting curve analysis from $65{ }^{\circ} \mathrm{C}$ to $95{ }^{\circ} \mathrm{C}$, with increments of $0.5{ }^{\circ} \mathrm{C}$ every $5 \mathrm{~s}$. Real-time PCR amplifications were conducted in triplicate. Primer sequences (Sigma-Aldrich, USA) for $P$. aeruginosa QS genes were used as described in Table $\mathrm{S} 1 . \dagger^{\mathbf{5 0}}$ The ribosomal gene $r p s L$ was chosen as a housekeeping gene to normalize the qRT-PCR data and to calculate the relative fold changes in gene expression. The fold change of target genes for each group with respect to the control group was calculated using the $\Delta \Delta C_{\mathrm{t}}$ method.

\section{Results and discussion}

In our previous report, we demonstrated the anti-QS and antibiofilm activities of the cold EtOAc extract of Tinospora cordifolia stem along with probable chemical constituents of the extract. ${ }^{\mathbf{4 0}}$ We selected four of these constituents (3-6, Fig. 2) based the molecular docking studies. The compounds were either synthesized (3 or 5) or procured from the vendors (4 and 6). While working with compound $\mathbf{6}$, we observed solubility issues (precipitation) at the concentrations tested. To circumvent these issues, the potassium salt of 6 (7, Scheme 1) was subsequently prepared, thoroughly characterized and then used in further studies.

\subsection{Evaluation of anti-quorum sensing activity}

3.1.1. Inhibition of short-chain AHL. Chromobacterium violaceum, a large, Gram-negative bacterium, produces shortchain AHL (C6-HSL) which regulates the production of natural antibiotic, a dark purple pigment - violacein (violet nondiffusible pigment). Reduction or absence of violacein is, thus, indicative of inhibition of short-chain AHL in C. violaceum. All four test compounds $(\mathbf{3 - 5}, 7)$ were evaluated for their ability to affect violacein production. As seen from Fig. 3(i), of all the compounds tested, only 7 could inhibit violacein production significantly (Fig. 3(i)(d) well 1, diameter of zone of pigment inhibition: $23 \mathrm{~mm}$ ) which was better than AZ (Fig. 3(i)(d) well 3, diameter of zone of pigment inhibition: $20 \mathrm{~mm}$ ) at the

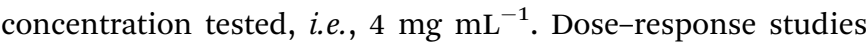
involving compound 7 at concentrations 4,6 and $8 \mathrm{mg} \mathrm{mL} \mathrm{m}^{-1}$ exhibited zone of pigment inhibition diameter as $22 \pm 1,25 \pm 1$ and $28 \pm 1 \mathrm{~mm}$, respectively. Inhibition of pigment production was not observed at lower concentrations, i.e., $2 \mathrm{mg} \mathrm{mL} \mathrm{mL}^{-1}$. Compound 7, from among the four test compounds, was a clear winner which inhibited short chain AHL production as seen from the presence of a colorless zone of inhibition against the purple lawn of $C$. violaceum. Though there was visible growth around the well (Fig. 3(i)(d)), there was no pigmentation at all, demonstrating inhibition of short-chain AHL molecule in $r h l$ QS circuitry with no antibacterial activity. Quantitative analysis of violacein pigment inhibition showed significant inhibition which support the anti-quorum sensing activity of compound 7. Growth curve analysis showed no antimicrobial activity at dose dependent manner of compound 7 (Fig. S1†).

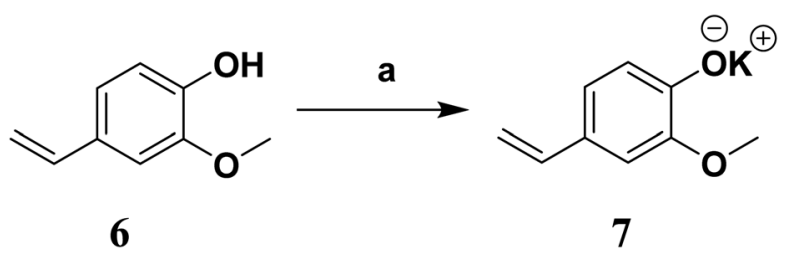

Scheme 1 Synthesis of potassium 2-methoxy-4-vinylphenolate (7). 
i.

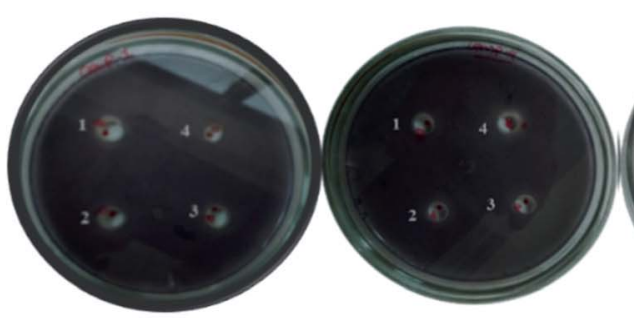

a

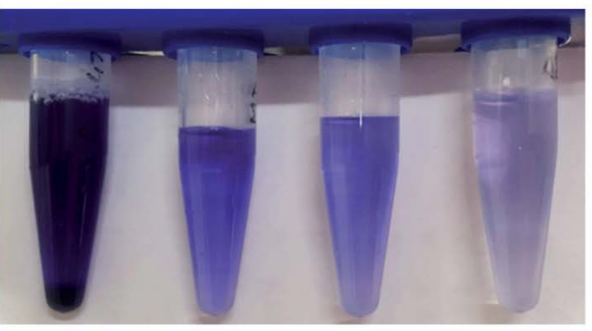

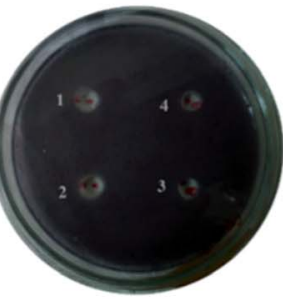

c

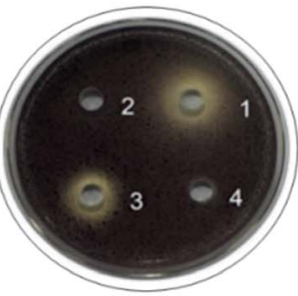

d ii. a.

iii. a.

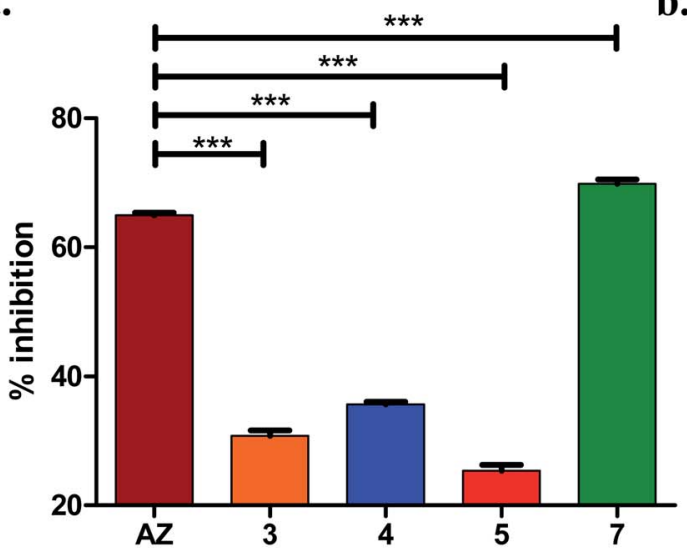

b. b.

\section{Quantitative analysis of violacein pigment}

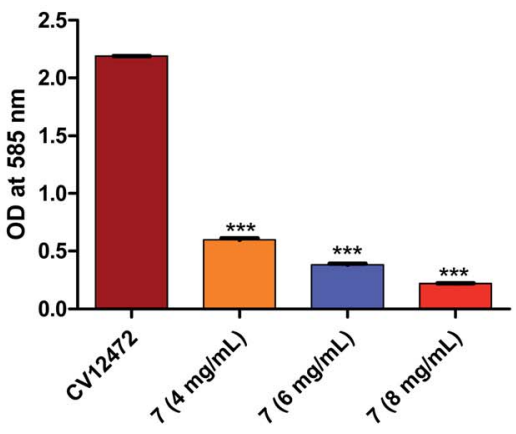

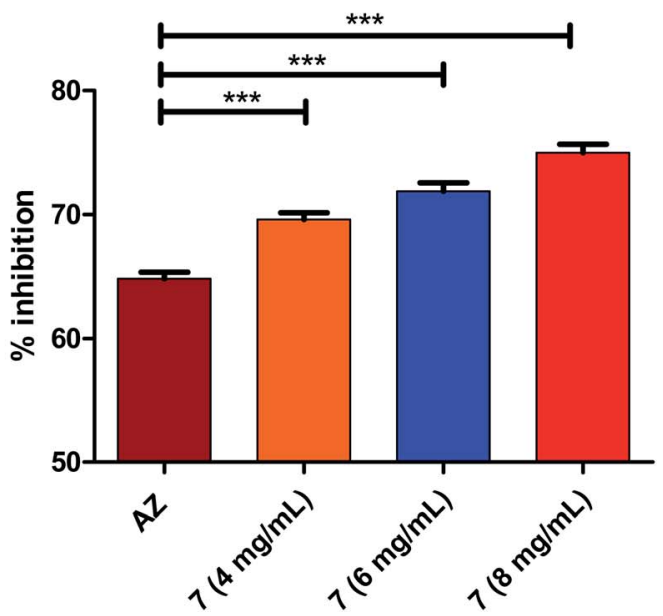

Fig. 3 (i) Inhibition of short-chain AHL in C. violaceum. (a) compound 3 - well 1: $4 \mathrm{mg} \mathrm{mL}^{-1}$, well 2: $6 \mathrm{mg} \mathrm{mL}^{-1}$, well 3: $8 \mathrm{mg} \mathrm{mL}^{-1}$, well 4:50\% DMSO (negative control); (b) compound 4 - well 1: $4 \mathrm{mg} \mathrm{mL}^{-1}$, well 2: $6 \mathrm{mg} \mathrm{mL}^{-1}$, well $3: 8 \mathrm{mg} \mathrm{mL}^{-1}$, well 4:50\% DMSO; (c) compound 5 - well 1: $4 \mathrm{mg} \mathrm{mL}^{-1}$, well 2: $6 \mathrm{mg} \mathrm{mL}^{-1}$, well 3: $8 \mathrm{mg} \mathrm{mL}^{-1}$, well 4: 50\% DMSO; (d) well 1 (compound 7): $4 \mathrm{mg} \mathrm{mL}^{-1}$, well 2: $50 \%$ DMSO, well 3 (azithromycin, positive control): $4 \mu \mathrm{gL}^{-1}$, well 4: PBS : EtOH (1:1) (negative control for AZ); (ii) quantitative analysis violacein pigment (a) tube method in dose dependent manner $\left(4 \mathrm{mg} \mathrm{mL}^{-1}, 6 \mathrm{mg} \mathrm{mL}^{-1}, 8 \mathrm{mg} \mathrm{mL}^{-1}\right.$ ); (b) graphical representation of violacein pigment inhibition. (iii) Inhibition of long-chain AHL assay in $P$. aeruginosa (a) by the test compounds $3\left(4 \mathrm{mg} \mathrm{mL}^{-1}\right), 4\left(4 \mathrm{mg} \mathrm{mL}^{-1}\right), 5\left(4 \mathrm{mg} \mathrm{mL}^{-1}\right), 7\left(4 \mathrm{mg} \mathrm{mL}^{-1}\right)$ and AZ $\left(4 \mu \mathrm{g} \mathrm{mL}^{-1}\right)(n=6)$; (b) dose-response studies of compound $7(n=3)$. Statistically significant difference between the test compounds compared to azithromycin (AZ) was analysed using Dunnett's multiple comparison test $(* * *=p<0.001)$.

3.1.2. Inhibition of long-chain AHL. The ability of a compound to inhibit long-chain AHL in $P$. aeruginosa was evaluated using a reporter strain, $E$. coli MG4/pKDT17, which detects 3-oxo- or 3-hydroxy C8-C14 long-chain AHL, which in turn, induces the expression of $\beta$-galactosidase gene. The decrease in $\beta$-galactosidase expression is, thus, indicative of 
long-chain AHL inhibition. Previously, Liu et al. have demonstrated similar activity, i.e., inhibition of 3OC12-HSL production in Pseudomonas aeruginosa, by small-molecule heterocyclic furanones. ${ }^{51}$ Of the several compounds tested, three compounds showed promising activity on LasIR.

As seen from Fig. 3(iii)(a), it was clearly evident that compound 7, compared to 3-5 and the positive control AZ (65 \pm $0.43 \%)$, showed remarkable inhibition (70 $\pm 0.62 \%)$ of longchain AHL at the concentration tested, i.e., $4 \mathrm{mg} \mathrm{mL}{ }^{-1}$. The observed activity, i.e., inhibition of long-chain AHL in P. aeruginosa, was indicative of the compound effect on the las QS circuitry. Further, the dose-response studies of compound 7 at 4, 6 and $8 \mathrm{mg} \mathrm{mL}{ }^{-1}$ were carried out. The results precisely indicated the dose-dependent increase in \% inhibition as $69 \pm$ $0.52 \%\left(4 \mathrm{mg} \mathrm{mL}^{-1}\right), 72 \pm 0.68 \%\left(6 \mathrm{mg} \mathrm{mL}^{-1}\right)$ and $75 \pm 0.69 \%(8$ $\left.\mathrm{mg} \mathrm{mL} \mathrm{m}^{-1}\right)$. Overall, the results were encouraging.

\subsection{Evaluation of anti-biofilm forming activity}

During biofilm formation, bacteria are covered in a matrix of extracellular polymeric substances (EPS) that hold microbial cells together onto a surface. Biofilm formation cycle of $P$. aeruginosa PAO1 can be divided into five major phenotypic steps. The progression commences by the reversible adhesion of planktonic bacteria onto the surface suitable for growth (Stage I), followed by irreversible attachment of bacteria, which thereafter form microcolonies in the EPS matrix (Stage II). Gradually, these microcolonies expand and their confluence leads to a more structured phenotype with noncolonized space (Stage III). Further, the noncolonized spaces are filled with bacteria, which finally cover the entire surface (Stage IV). Finally, the bacteria disperse from the sessile structure and reenter in the planktonic state to spread and colonize other surfaces (Stage V). ${ }^{52}$

Compound 7 demonstrated statistically significant $(p<$ 0.001) dose-dependent increase in the anti-biofilm forming activity (as assessed by crystal violet staining) in $24 \mathrm{~h}$ treated culture of Pseudomonas aeruginosa PAO1 (Fig. 4(i)) compared to the positive control, AZ. The corresponding values were AZ (66 $\pm 0.3 \%), 7-4 \mathrm{mg} \mathrm{mL}^{-1}(76 \pm 0.24 \%), 6 \mathrm{mg} \mathrm{mL}^{-1}(79 \pm 0.28 \%)$ and $8 \mathrm{mg} \mathrm{mL}^{-1}(82 \pm 0.2 \%)$. The results were in line with earlier anti-QS activity outcome (Fig. 3). The spinning-disc confocal microscopy studies corroborated the results from anti-QS and anti-biofilm forming activity studies (Fig. 4(ii)). As precisely seen in Fig. 4(ii)(A-C), the number of dead cells (red stained) increased while the viable cell (green stained) number decreased in dose-dependent manner compared to the untreated control (Fig. 4(ii)(D)), which was attributed to the increased cell-killing (in the absence of antibacterial activity of 7) due to biofilm inhibition. Azithromycin, at the concentration tested, also showed inhibition of biofilm formation, albeit to lesser extent as assessed qualitatively from Fig. 4(ii)(E). The higher number of red stained (dead) cells signifies a greater number of static cells present onto the surface, which in turn, denote the reduced biofilm formation.

In consonance with our previous report, ${ }^{40}$ where we postulated the hits (compound 6) would bind to LasR as supported by the molecular docking analysis, it made perfect sense that 7 would inhibit biofilm formation in Pseudomonas aeruginosa by interfering one of the QS circuitries (las, rhl or $p q s$ ), preferably las. In summary, these preliminary results with 7 encouraged us to further evaluate it in the anti-virulence assays.

To gain further insights into structural requirements for biofilm inhibition, we studied literature reports detailing the structure-activity relationship (SAR) around 2-methoxyphenols bearing 4-substituent [H (Guaiacol), ethyl (4-ethylguaiacol), allyl (eugenol), 2-methylvinyl (isoeugenol) and propyl (2-methoxy-4propylphenol)] which can easily be compared with compound 7 (Fig. S2 $\dagger$ ). The report $^{52}$ discussed the inhibition of biofilm formation in one of the Gram-negative microorganisms, E. coli O157:H7 by essential oils (containing eugenol-like compounds). It was found that the presence of double bond as part of 4substituent, clearly imparted significant biofilm inhibitory activity to the studied compounds. The order of activity with respect to biofilm inhibition was - eugenol $>$ isoeugenol $>2$ methoxy-4-propylphenol > 4-ethylguaiacol $>$ guaiacol. The hydrophobic substitution at position 4 on the 2-methoxyphenol led to increased activity. Further potentiation of activity was observed when the substituent with unsaturation was used. The study $^{53}$ provided important clues with respect to structural requirement for biofilm inhibitory activity in Gram-negative microbes. The presence of $\mathrm{C}=\mathrm{C}$ bond at position 4 on the aromatic ring, keeping other substituents constant, made the major impact on biofilm formation. Given the strict structural requirements at position 4 , it can be postulated that the 4 substituent played an important role in modulating the biofilm inhibition possibly by interacting with appropriate target(s) in the QS circuitry in the Gram-negative microbes.

\subsection{Anti-virulence assays}

3.3.1. Swarming activity. Pseudomonas aeruginosa is capable of concerted and rapid movement across a semisolid or more precisely, viscous surfaces, i.e., swarming motility, significantly affected by a lot of genes. It is typified by the translocation of the bacterial population across growth media. In this assay, the test compound, in specified concentrations, were added to the media and the bacterial culture was pointinoculated. Swarming motility (measured in $\mathrm{mm}$ ) was observed on the semisolid agar plate, as seen in Fig. 5 . The Pseudomonas aeruginosa PAO1 cells, in the absence of the test compound, formed tendrils migrating outwards or away from the inoculation point, with continued branching during this process. In contrast, in presence of the test compound, bacterial cells grew to form a localized colony in the center of the plate, with no signs of swarming. The ability of several synthetic compounds to disrupt the QS-regulated swarming motility in $P$. aeruginosa was demonstrated previously. ${ }^{54}$ Thus, the manifestation of anti-QS property in the form of inhibition of swarming motility in $P$. aeruginosa further unequivocally supported the proposed quorum quenching property of 7 in dose-dependent manner.

3.3.2. Inhibition of LasA protease and LasB elastase. LasA protease is a staphylolytic endoprotease enzyme regulated by 
i.

Biofilm inhibition assay

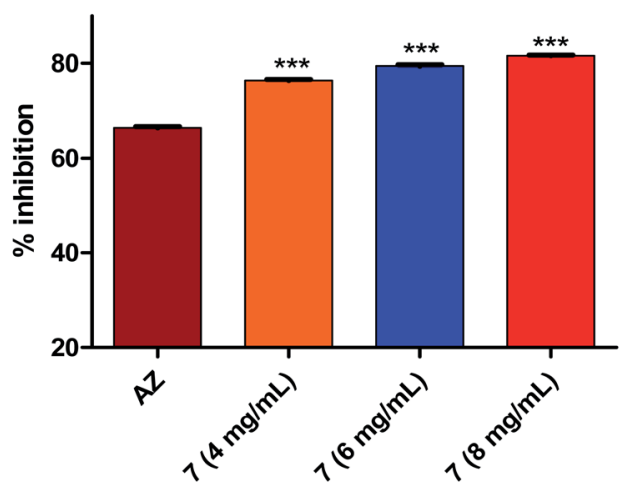

ii.
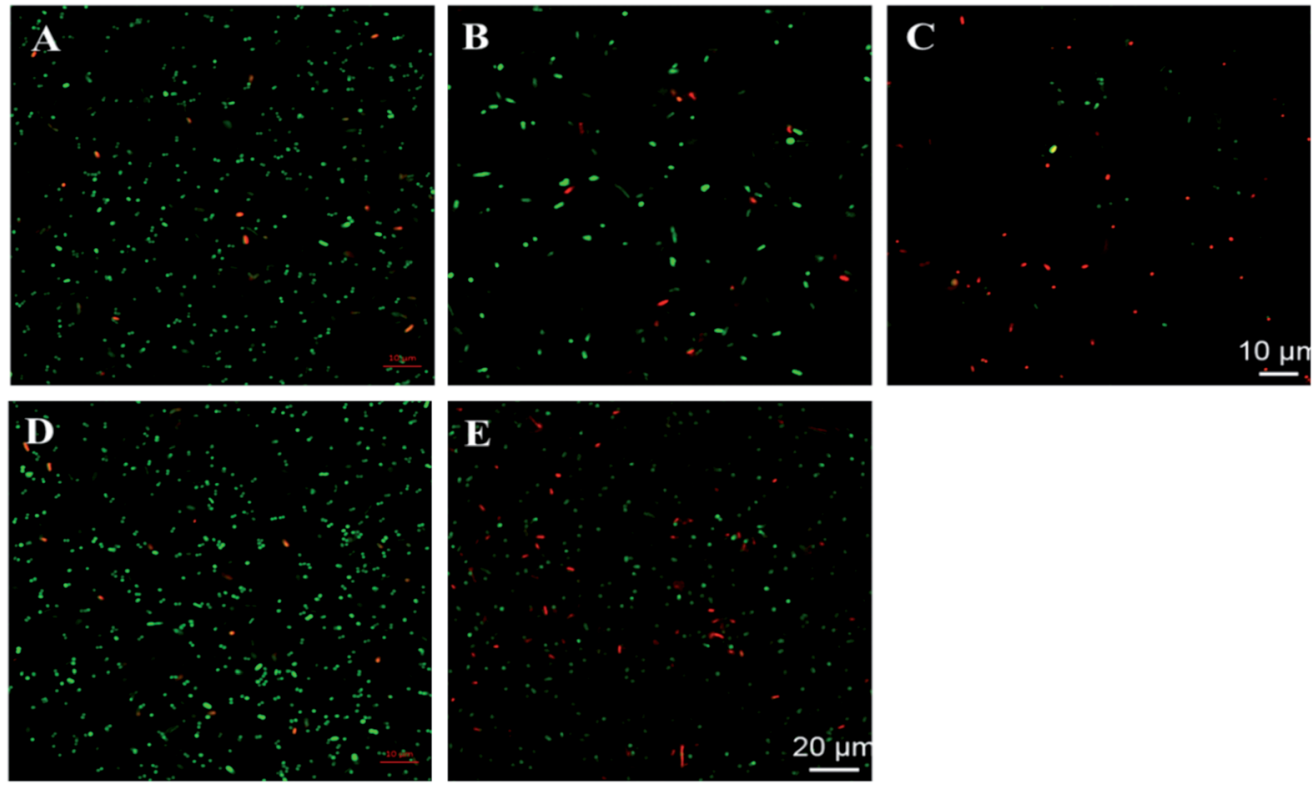

Fig. 4 (i) Dose-dependent anti-biofilm forming activity of 7 in 24 h-treated culture of Pseudomonas aeruginosa PAO1 ( $n=9$ ). The asterisk above bars indicate statistically significant difference compared to AZ $\left(4 \mu \mathrm{g} \mathrm{mL}^{-1}\right)$ based on Dunnett's multiple comparison test (*** $\left.=p<0.001\right)$. (ii) Spinning-disc confocal laser microscopy micrographs of $24 \mathrm{~h}$ old $P$. aeruginosa PAO1 biofilms treated with various concentrations of 7 . Bacterial viability was determined using SYTO-9 and propidium iodide dyes. Exposure to (A) $4 \mathrm{mg} \mathrm{mL}^{-1}$, (B) $6 \mathrm{mg} \mathrm{mL}^{-1}$, (C) $8 \mathrm{mg} \mathrm{mL}^{-1}$, (D) no exposure, (E) AZ $\left(4 \mu \mathrm{g} \mathrm{mL}^{-1}\right)$. Cells stained red are dead while cells stained green are viable cells. The scale bar represents $20 \mu \mathrm{m}$.

LasIR circuit in $P$. aeruginosa. During the assay, $S$. aureus suspension was used as a substrate, wherein the enzymatic activity was measured spectrophotometrically at $600 \mathrm{~nm}$.
Compound 7 ( $\left.4 \mathrm{mg} \mathrm{mL}{ }^{-1}\right)$ and $\mathrm{AZ}\left(4 \mu \mathrm{g} \mathrm{mL} \mathrm{m}^{-1}\right)$ inhibited LasA protease enzyme significantly, i.e., $75 \pm 0.8 \%$ and $82.5 \pm 0.6 \%$, respectively (Fig. 6(i)). Further, the dose-response study

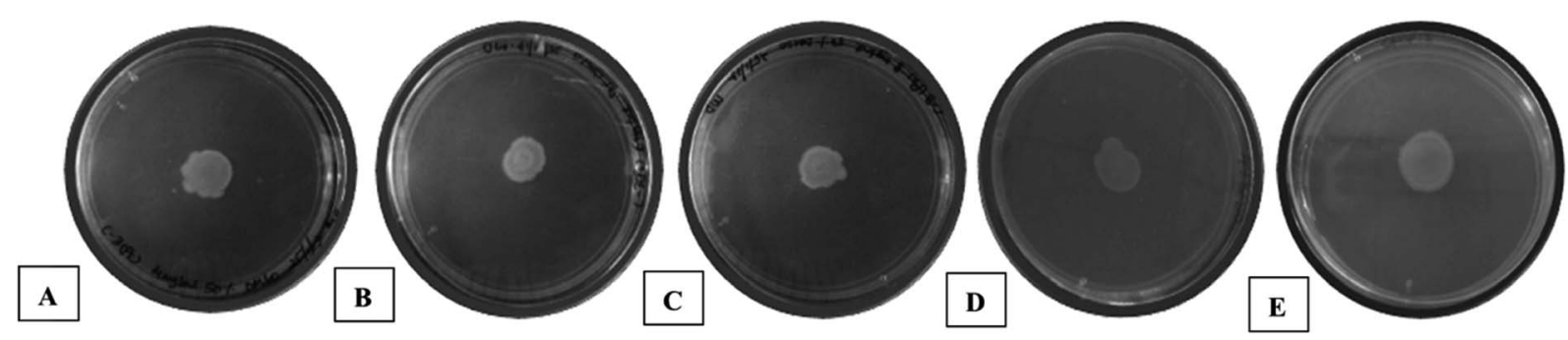

Fig. 5 Inhibition of swarming activity of $P$. aeruginosa by compound 7 in dose-dependent manner - (A) $4 \mathrm{mg} \mathrm{mL}^{-1}\left(16.5 \pm 1 \mathrm{~mm}^{2}\right.$, (B) $6 \mathrm{mg} \mathrm{mL}^{-1}$ $(15 \pm 1.3 \mathrm{~mm}),(C) 8 \mathrm{mg} \mathrm{mL}^{-1}(14 \pm 1 \mathrm{~mm})$ along with (D) negative control (50\% DMSO) $(20.5 \pm 1.2 \mathrm{~mm})$ and (E) untreated $P$. aeruginosa (21.5 \pm 1 $\mathrm{mm})$. 
i.

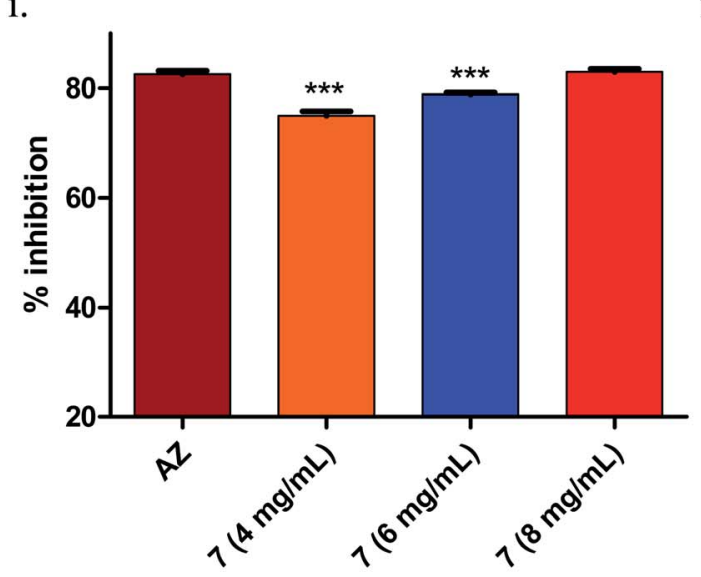

ii.

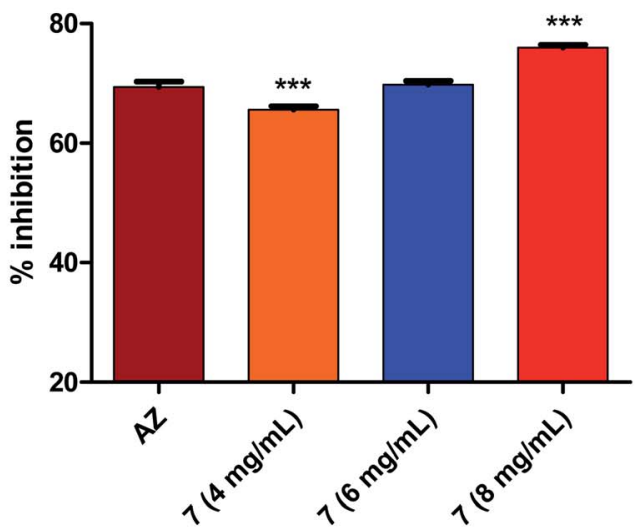

iii.

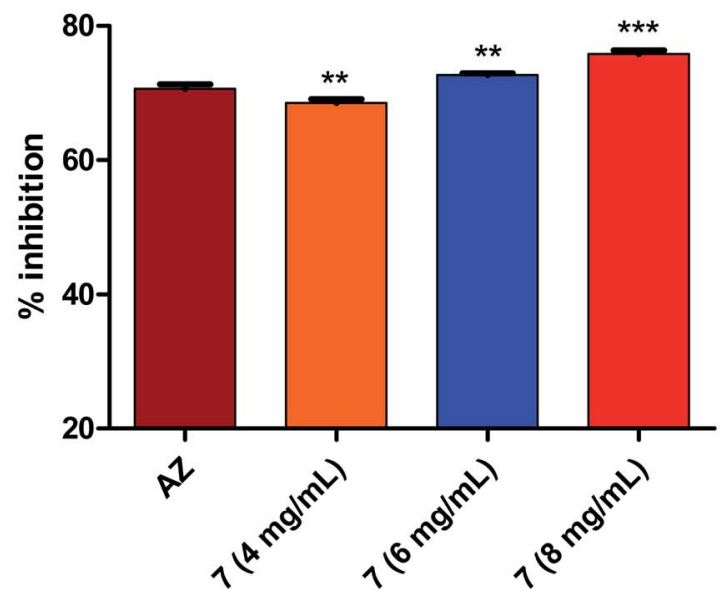

Fig. 6 Dose-dependent activity of compound 7 on virulence factors - (i) LasA protease; (ii) LasB elastase and (iii) pyocyanin in P. aeruginosa PAO1 $(n=3)$. The asterisk above bars indicate statistically significant difference compared to AZ using Dunnett's multiple comparison test ( $* * *=$ $p<0.001, * *=p<0.05)$.

involving 7 exhibited marginal increase in LasA protease \% inhibition from $4 \mathrm{mg} \mathrm{mL}^{-1}$ to $8 \mathrm{mg} \mathrm{mL}^{-1}$ (Fig. 6(i)). On the similar lines, LasB elastase enzyme degrades elastin and collagen proteins in the lung tissues. For the evaluation of extent of LasB elastase inhibition by the test compounds, elastin Congo red (ECR) was employed as a substrate, where LasB degraded the elastin and Congo red was liberated. The red color produced by the liberated congo red was measured spectrophotometrically at $495 \mathrm{~nm}$. Compound $7\left(4 \mathrm{mg} \mathrm{mL}^{-1}\right)$ and $\mathrm{AZ}$ $\left(4 \mu \mathrm{g} \mathrm{mL}{ }^{-1}\right)$ significantly inhibited LasB elastase enzyme (65.5 \pm $0.6 \%$ and $69.5 \pm 0.87 \%$, respectively) (Fig. 6(ii)). Slight increase in the LasB elastase \% inhibition was observed with increasing doses (4 to $8 \mathrm{mg} \mathrm{mL}^{-1}$ ) (Fig. 6(ii)). Protease and elastase (regulated by the las circuitry) play vital roles in colonizing host tissues.

Hentzer et al. synthesized halogenated furanones (produced by Australian red macro-alga Delisea pulchra) and checked antiquorum sensing and anti-virulence activity in $P$. aeruginosa. As a result of that study, furanones showed inhibition in quorum sensing and virulence factors like LasA protease and elastase. ${ }^{55}$
3.3.3. Pyocyanin assay. Pyocyanin, a blue-green pigment produced by $P$. aeruginosa, is regulated by $r h l \mathrm{QS}$ circuitry and is implicated in both acute and chronic infections causing multiple devastating effects majorly by reactive oxygen species (ROS) generation. King's B medium is used specifically for pyocyanin pigment production. Previously, O'Loughlin et al. demonstrated that $m$-bromothiolactone (mBTL) significantly inhibited pyocyanin pigmentation in $P$. aeruginosa in vitro and in vivo. ${ }^{56}$ Test compound $7\left(4 \mathrm{mg} \mathrm{mL}^{-1}, 68.5 \pm 0.56 \%\right)$ and $\mathrm{AZ} \mathrm{(4}$ $\left.\mu \mathrm{g} \mathrm{mL}^{-1}, 71 \pm 0.61 \%\right)$ significantly inhibited pyocyanin pigment production (Fig. 6(iii)). Further, marginal increase in $\%$ inhibition of pyocyanin production was noted with increasing dose $\left(4,6\right.$ and $\left.8 \mathrm{mg} \mathrm{mL}^{-1}\right)$ of 7 , indicating Pseudomonas aeruginosa virulence inhibition.

3.3.4. Twitching motility. Twitching motility in P. aeruginosa is a flagellum-independent mode of surface translocation under humid conditions on semisolid/solid surfaces, which requires functional type IV pili (T4P). Twitching motility is necessary for $P$. aeruginosa biofilm development. ${ }^{.77}$ It is the first step towards biofilm formation wherein the twitching motility 

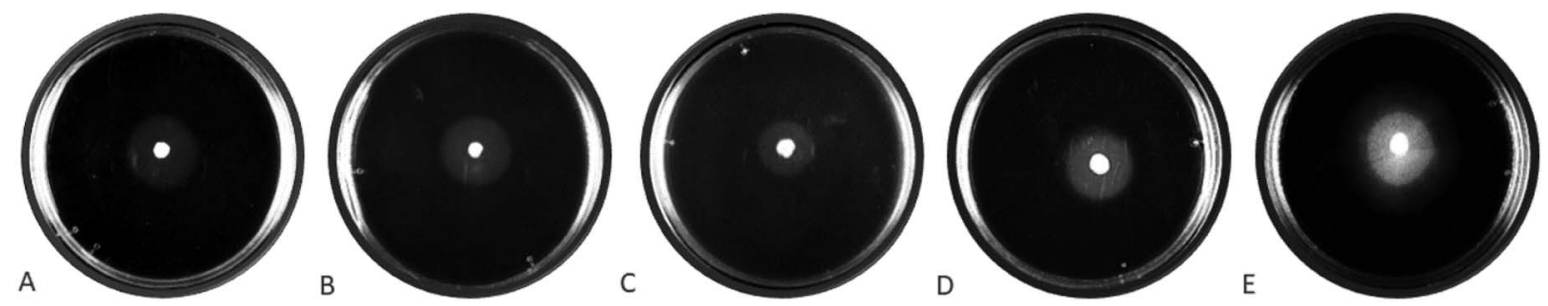

Fig. 7 Twitching motility exhibited by compound 7 following treatment with (A) $4 \mathrm{mg} \mathrm{mL}^{-1}$ (24.5 $\left.\pm 1.5 \mathrm{~mm}\right)$; (B) $6 \mathrm{mg} \mathrm{mL}$ (22 $\pm 1 \mathrm{~mm}$ ); (C) $8 \mathrm{mg}$ $\mathrm{mL}^{-1}(17 \pm 1.5 \mathrm{~mm})$; (D) AZ (positive control, $23.5 \pm 1 \mathrm{~mm}$ ) and (E) P. aeruginosa PAO1 $(30.5 \pm 1.5 \mathrm{~mm})$.

aids bacterial attachment to the solid surfaces forming the biofilm. Thus, this phenomenon is so clearly associated with high cell densities and cell-cell communication, which are the hallmarks of QS systems in bacteria. ${ }^{58}$ In the macroscopic twitching assay, Pseudomonas aeruginosa culture is stabbed through a layer of agar to the base of the plate, usually plastic, and the large halo of interstitial colony expansion is observed in the plate. As seen in Fig. 7, compound 7, with increasing concentration $\left(4,6\right.$ and $\left.8 \mathrm{mg} \mathrm{mL}{ }^{-1}\right)$, reduced the twitching motility in Pseudomonas aeruginosa, which was comparable to the positive control AZ (Fig. 7(B) and (D)) or even better than AZ (Fig. 7(C) and (D)). It was clearly evident from Fig. 7 that 7 significantly reduced the twitching motility in Pseudomonas aeruginosa in dose-dependent manner.

\subsection{Gene regulation}

Studies on down regulation of LasIR and RhlIR circuitry have been done using real time PCR. Phenotypic assays showed inhibition of biofilm and virulence factors in P. aeruginosa. To confirm the same at genetic level, real time PCR was performed and observed significant down regulation (in terms of fold change) of all four genes viz lasI, rhlI, lasR and rhlR as concentration of compound 7 increase $\left(2 \mathrm{mg} \mathrm{mL}^{-1}, 4 \mathrm{mg} \mathrm{mL}{ }^{-1}, 6 \mathrm{mg}\right.$ $\mathrm{mL}^{-1}$ and $8 \mathrm{mg} \mathrm{mL}^{-1}$ ) in the presence of housekeeping gene (rpsL) (Fig. S3 $\dagger$ ). Result confirms the inhibition of both circuitry LasIR and RhlIR in P. aeruginosa PAO1. In fact, down regulation of these genes confirms the inhibition of biofilm and other virulence factors. The lasI-lasR and $r h l \mathrm{I}-r h l \mathrm{R}$ quorum sensing systems regulate expression of various virulence genes and play an important role in biofilm formation. Luo et al. reported that baicalin (5,6,7-trihydroxyflavone, flavonoid monomer purified from Scutellaria baicalensis) significantly repressed all four gene in Pseudomonas aeruginosa strain. ${ }^{59}$ Similar study was conducted by Hossain et al. where methyl gallate (phenolic compound) significantly down regulated all four genes. ${ }^{60}$

\section{Conclusion}

Inhibition of QS in Pseudomonas aeruginosa remains an elusive target for tackling the menace of its MDR strains and the subsequent complications. Continuing on the same path, in the present study, our group extensively investigated the potential of previously identified small-molecule QS inhibitors (from Tinospora cordifolia stem EtOAc extract) in the QS, biofilmformation, and virulence inhibition assays. Of the initial four hits, compound 7 was a clear winner. It exhibited significant anti-QS, anti-biofilm forming and anti-virulence activities in relevant assays in dose-dependent manner. Compound 7 also down regulated all four genes responsible for quorum sensing in $P$. aeruginosa in dose dependent manner. The activities were comparable or even better than the positive control AZ at the doses tested. Given the tiny structure of 7 , there is so much scope for further structural modifications and functional studies centered on it. These results were in line with other reports with respect to the structural requirements for biofilm inhibitory activity by 4-substituted 2-methoxyphenols. The discovery of hit 7 is just the beginning of the story. The results reported in the present study are likely to motivate researchers in the field to further explore it.

\section{Funding}

This research did not receive any specific grant from funding agencies in the public, commercial, or not-for-profit sectors.

\section{Conflicts of interest}

We do not have any conflicts of interest to declare.

\section{Acknowledgements}

The authors deeply acknowledge Sophisticated Analytical Instrument Facility (SAIF), Indian Institute of Technology Bombay (IIT-B), Mumbai, India for confocal analysis. MS thanks SVKM's NMIMS (Deemed to be University), Mumbai, India for providing the necessary facilities. We also thanks Mr Mitesh Joshi, SVKM's NMIMS, Sunandan Divatia School of Science for his help with the artwork.

\section{References}

1 A. G. Tedros, Prioritization of pathogens to guide discovery, research and development of new antibiotics for drug-resistant bacterial infections, including tuberculosis, World Health Organisation, Geneva, December, 2017.

2 Antimicrobial resistance, World Health Organization, 1998, 16.

3 A. Y. Bhagirath, Y. Li, R. Patidar, K. Yerex, X. Ma, A. Kumar and K. Duan, Int. J. Mol. Sci., 2019, 20, 1781. 
4 D. M. Sievert, P. Ricks, A. J. Kallen, J. R. Edwards, A. Schneider, J. Patel, A. Srinivasan, B. Limbago and S. Fridkin, Infect. Control Hosp. Epidemiol., 2013, 14, 1-14.

5 N. Lynn, G. Joshua, G. Katherine and M. Conan, ContagionLive, Infectious Diseases Today, 2018, 20, 1-6.

6 S. B. Vickery, D. McClain and K. A. Wargo, Pharmacotherapy, 2016, 36, e154-e159.

7 I. Agnese, M. Haenni and J. Y. Madec, Microbiol. Spectrum, 2018, 6, 1-16.

8 M. S. Mulani, E. E. Kamble, S. N. Kumkar, M. S. Tawre and K. R. Pardesi, Front. Microbiol., 2019, 10, 1-12.

9 T. L. Tagliaferri, M. Jansen and H.-P. Horz, Front. Cell. Infect. Microbiol., 2019, 9, 1-13.

10 G. G. Zhanel, A. R. Golden, S. Zelenitsky, K. Wiebe, C. K. Lawrence, H. J. Adam, T. Idowu, R. Domalaon, F. Schweizer, M. A. Zhanel, P. R. S. Lagacé-Wiens, A. J. Walkty, A. Noreddin, J. P. Lynch and J. A. Karlowsky, Drugs, 2019, 79, 271-289.

11 D. R. Giacobbe, M. Mikulska and C. Viscoli, Expert Rev. Clin. Pharmacol., 2018, 11, 1219-1236.

12 M. Shaaban, A. Elgaml and E. S. E. Habib, Microb. Pathog., 2018, 127, 138-143.

13 S. Mukherjee and B. L. Bassler, Nat. Rev. Microbiol., 2019, $7(6), 371-382$.

14 W.-L. Ng and B. L. Bassler, Annu. Rev. Genet., 2009, 43, 197222.

15 S. T. Rutherford and B. L. Bassler, Cold Spring Harbor Perspect. Med., 2012, 2, 1-25.

16 M. J. Gambello and B. H. Iglewski, J. Bacteriol., 1991, 173, 3000-3009.

17 J. P. Pearson, K. M. Gray, L. Passador, K. D. Tucker, A. Eberhard, B. H. Iglewski and E. P. Greenberg, Proc. Natl. Acad. Sci. U. S. A., 1994, 91, 197-201.

18 J. P. Pearson, L. Passador, B. H. Iglewski and E. P. Greenberg, Proc. Natl. Acad. Sci. U. S. A., 1995, 92, 1490-1494.

19 O. Fleitas Martínez, P. O. Rigueiras, Á. da S. Pires, W. F. Porto, O. N. Silva, C. de la Fuente-Nunez and O. L. Franco, Front. Cell. Infect. Microbiol., 2018, 8, 1-17.

20 S. Haque, D. K. Yadav, S. C. Bisht, N. Yadav, V. Singh, K. K. Dubey, A. Jawed, M. Wahid and S. A. Dar, J. Chemother., 2019, 1-27.

21 N. D. Paguigan, J. Rivera-Chávez, J. J. Stempin, M. Augustinović, A. I. Noras, H. A. Raja, D. A. Todd, K. D. Triplett, C. Day, M. Figueroa, P. R. Hall, N. B. Cech and N. H. Oberlies, J. Nat. Prod., 2019, 82, 550-558.

22 J. Chen, B. Wang, Y. Lu, Y. Guo, J. Sun, B. Wei, H. Zhang and H. Wang, Mar. Drugs, 2019, 17, 80.

23 X. Chen, L. Zhang, M. Zhang, H. Liu, P. Lu and K. Lin, Expert Opin. Ther. Pat., 2018, 28, 849-865.

24 S. Manner and A. Fallarero, Int. J. Mol. Sci., 2018, 19(5), 1346.

25 S. A. Ahmed, M. Rudden, T. J. Smyth, J. S. G. Dooley, R. Marchant and I. M. Banat, Appl. Microbiol. Biotechnol., 2019, 103, 3521-3535.

26 J. Fong, K. T. Mortensen, A. Nørskov, K. Qvortrup, L. Yang, C. H. Tan, T. E. Nielsen and M. Givskov, Front. Cell. Infect. Microbiol., 2019, 8, 1-11.
27 B. Almohaywi, T. T. Yu, G. Iskander, D. S. H. Chan, K. K. K. Ho, S. Rice, D. S. C. Black, R. Griffith and N. Kumar, Bioorg. Med. Chem. Lett., 2019, 29(9), 1054-1059. 28 J. E. Paczkowski, A. R. McCready, J. P. Cong, Z. Li, P. D. Jeffrey, C. D. Smith, B. R. Henke, F. M. Hughson and B. L. Bassler, ACS Chem. Biol., 2019, 14, 378-389.

29 M. Kalia, V. K. Yadav, P. K. Singh, S. Dohare, D. Sharma, S. S. Narvi and V. Agarwal, 3 Biotech, 2019, 9(2), 40.

30 M. N. Qiu, F. Wang, S. Y. Chen, P. C. Wang, Y. H. Fu, Y. Y. Liu, X. Wang, F. B. Wang, C. Wang, H. W. Yang, Y. Wu, S. Y. Zhu, H. B. Zhou, W. M. Chen, J. Lin, J. X. Zheng and P. H. Sun, Bioorg. Med. Chem. Lett., 2019, 29, 749-754.

31 M. Goswami, A. Espinasse and E. E. Carlson, Chem. Sci., 2018, 9, 7332-7337.

32 M. M. Saleh, H. A. Abbas and M. M. Askoura, Microb. Pathog., 2019, 127, 31-38.

33 Y. Bin Li, J. Liu, Z. X. Huang, J. H. Yu, X. F. Xu, P. H. Sun, J. Lin and W. M. Chen, Eur. J. Med. Chem., 2018, 158, 753766.

34 F. D'Angelo, V. Baldelli, N. Halliday, P. Pantalone, F. Polticelli, E. Fiscarelli, P. Williams, P. Visca, L. Leoni and G. Rampioni, Antimicrob. Agents Chemother., 2018, 62(11), e01296-18.

35 F. Soukarieh, P. Williams, M. J. Stocks and M. Cámara, J. Med. Chem., 2018, 61, 10385-10402.

36 B. Almohaywi, A. Taunk, D. S. Wenholz, S. Nizalapur, N. N. Biswas, K. K. K. Ho, S. A. Rice, G. Iskander, D. S. C. Black, R. Griffith and N. Kumar, Molecules, 2018, 23(5), 1106.

37 M. R. Tapia-Rodriguez, A. Hernandez-Mendoza, G. A. Gonzalez-Aguilar, M. A. Martinez-Tellez, C. M. Martins and J. F. Ayala-Zavala, Food Control, 2017, 75, 255-261.

38 J. Luo, J. L. Kong, B. Y. Dong, H. Huang, K. Wang, L. H. Wu, C. C. Hou, Y. Liang, B. Li and Y. Q. Chen, Drug Des., Dev. Ther., 2016, 10, 183-203.

39 H. S. Kim, S. H. Lee, Y. Byun and H. D. Park, Sci. Rep., 2015, $5,8656$.

40 V. Gala, N. John, A. Bhagwat, A. Datar, P. Kharkar and K. Desai, Indian J. Med. Res., 2016, 144, 92.

41 B. N. Singh, B. R. Singh, R. L. Singh, D. Prakash, B. K. Sarma and H. B. Singh, Food Chem. Toxicol., 2009, 47, 778-786.

42 J. P. Kirwan, T. A. Gould, H. P. Schweizer, S. W. Bearden, R. C. Murphy and M. E. A. Churchill, Society, 2006, 188, 784-788.

43 T. Mathur, S. Singhal, S. Khan, D. Upadhyay, T. Fatma and A. Rattan, Indian J. Med. Microbiol., 2006, 24, 25-29.

44 M. S. a Khan, M. Zahin, S. Hasan, F. M. Husain and I. Ahmad, Lett. Appl. Microbiol., 2009, 49, 354-360.

45 E. Kessler, M. Safrins, J. C. Olsonll and D. E. Ohmanll, J. Biol. Chem., 1993, 268, 7503-7508.

46 N. R. John, V. C. Gala and C. S. Sawant, Int. J. Pharma Bio Sci., 2013, 4, 487-495.

47 J. P. Pearson, E. C. Pesci and B. H. Iglewski, J. Bacteriol., 1997, 179(18), 5756-5767. 
48 V. Huerta, K. Mihalik, S. H. Crixell and D. a. Vattem, Int. J. Appl. Res. Nat. Prod., 2008, 1, 9-15.

49 S. Datta, D. Jana, T. R. Maity, A. Samanta and R. Banerjee, 3 Biotech, 2016, 6, 1-6.

50 H. Li, X. Li, Z. Wang, Y. Fu, Q. Ai, Y. Dong and J. Yu, BMC Microbiol., 2015, 15, 1-8.

51 H. B. Liu, J. H. Lee, J. S. Kim and S. Park, Biotechnol. Bioeng., 2010, 106, 119-126.

52 T. Rasamiravaka, Q. Labtani, P. Duez and M. El Jaziri, BioMed Res. Int., 2015, 2015, 1-17.

53 Y. G. Kim, J. H. Lee, G. Gwon, S. Il Kim, J. G. Park and J. Lee, Sci. Rep., 2016, 6, 36377.

54 H. Oura, Y. Tashiro, M. Toyofuku, K. Ueda, T. Kiyokawa, S. Ito, Y. Takahashi, S. Lee, H. Nojiri, T. Nakajima-Kambe, H. Uchiyama, H. Futamata and N. Nomura, Appl. Environ. Microbiol., 2015, 81, 2808-2818.
55 M. Hentzer, H. Wu, J. B. Andersen, K. Riedel, T. B. Rasmussen, N. Bagge, N. Kumar, M. a. Schembri, Z. Song, P. Kristoffersen, M. Manefield, J. W. Costerton, S. Molin, L. Eberl, P. Steinberg, S. Kjelleberg, N. Høiby and M. Givskov, EMBO J., 2003, 22, 3803-3815.

56 C. T. O. Loughlin, L. C. Miller, A. Siryaporn, K. Drescher and M. F. Semmelhack, Proc. Natl. Acad. Sci. U. S. A., 2013, 110(44), 17981-17986.

57 G. A. O'Toole and R. Kolter, Mol. Microbiol., 1998, 30, 295304.

58 A. Glessner, R. S. Smith, B. H. Iglewski and J. B. Robinson, J. Bacteriol., 1999, 181, 1623-1629.

59 J. Luo, B. Dong, K. Wang, S. Cai, T. Liu, X. Cheng, D. Lei, Y. Chen, Y. Li, J. Kong and Y. Chen, PLoS One, 2017, 12, 1-32. 60 M. A. Hossain, S. J. Lee, N. H. Park, A. F. Mechesso, B. T. Birhanu, J. Kang, M. A. Reza, J. W. Suh and S. C. Park, Sci. Rep., 2017, 7, 1-16. 